\title{
チーズの旨味と乳酸菌
}

チーズの美味しさは, カゼインが分解されて生じた呈味性のペプチド及び遊離アミノ酸による。チーズ中 には乳に存在するプラスミンと乳を固めるために添加する凝乳酵素が含まれているが，これらの酵素は何れ もタンパク質をペプチドまでしか分解しない。スターターとして乳酸球菌と乳酸桿菌が使用されるがこれら の菌がタンパク質分解酵素プロティナーゼの他にペプチダーゼを分泌する。乳酸菌は自己溶菌により菌体外 に放出されるペプチダーゼでペプチドを遊離アミノ酸に変える。この様なチーズ熟成中の酵素や乳酸菌によ るタンパク質分解の働きについて解説して貫った。

\section{佐々木 正弘}

\section{1.はじめに}

日本の食文化になくてはならなくなったチーズ。そ の中でも芳醇な香りを持つものは, ビールやワインの おつまみとして絶品である。チーズはナチュラルチー ズと何種類かのナチュラルチーズをブレンドして加熱 および乳化させたプロセスチーズに大きく分類される。 その中でゴーダおよびチェダーはセミハード／ハード チーズに分類される硬い組織のナチュラルチーズであ り，プロセスチーズの原料としても幅広く使用されて いる。そのため, 日本人には馴染みの深い味わいをも つている。

このゴーダおよびチェダーは, 乳を凝固させてダイ ス状にカットし，加温と攪拌で粒状にした後, 型に詰 めてプレスして硬い組織にして製造される。そして， $4 \sim 15^{\circ} \mathrm{C}$ 低温で適切な管理をして熟成させることに より特有の風味がでてくる。通常, 熟成期間は 1 ケ月 〜2 年程かかり, 風味のバランスもあるが, 熟成期間 の長いものほど濃厚で美味しいチーズとなる。このチ 一ズの美味しさのうち, 大部分は乳タンパク質である カゼインが分解されることにより生じる呈味性のペプ チドおよび遊離アミノ酸によるものであり，特に遊離 アミノ酸の生成は, チーズ中の乳酸菌の働きによると ころが大きい。つまり, 熟成されたチーズの芳醇な旨 味は, 製造時に添加するスタータ一乳酸菌や殺菌乳に 僅かに含まれる非スターター乳酸菌の様々なタンパク 質分解酵素群が複雑に関与しながら形成される。
本稿では, ゴーダおよびチェダーを中心としたセミ ハード／ハードチーズの美味しさについて, 近年 EU を中心に精力的に行われてきた乳酸菌研究の成果とそ のチーズへの応用例を中心に解説する。

\section{2. チーズ中のタンパク質分解酵素}

乳酸菌の説明の前に乳酸菌以外のチーズの熟成に関 わるタンパク質分解酵素について概説したい。タンパ ク質がアミノ酸に分解されるまでに, (1)タンパク質 $\rightarrow$

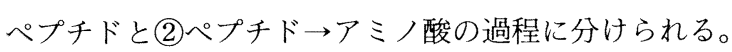
(2)の過程は主に乳酸菌のタンパク質分解酵素が受け持 つが, (1)の過程は乳に元来存在するプラスミンとチー ズ製造の際に乳を固めるために添加する凝乳酵素がそ の役割を担っている。

プラスミンはフィブリンの溶解性に関与する血液成 分である。乳中には血液からの漏出により, その前駆 体であるプラスミノーゲン $(\mathrm{zP})$, それを活性化する プラスミノーゲンアクチベーター $(z \mathrm{PA}), z \mathrm{PA}$ を阻 害するプラスミノーゲンアクチベーター・インヒビタ 一（zPA-I）およびプラスミンを阻害するプラスミン インヒビター $(\mathrm{P}-\mathrm{I})$ が存在する。プラスミン, $z \mathrm{P}$ お び $z \mathrm{PA}$ はカゼインミセルに存在し, 阻害剤の zPA-I および P-I は液体のホエイ (乳清) 中に含まれてい る。チーズ製造をした場合，前者のグループはチーズ カードとして残り, 後者のグループは排出される。つ まり，乳中では活性が抑えられていたプラスミンは， チーズの型詰めが終了した後に活性化されてカゼイン

Umami in Cheese by Lactic Acid Bacteria

Masahiro SAsaki (Product Planning Department, Snow Brand Milk Products Co., Ltd.) 
の分解を始めることとなる。この酵素は, 至適 $\mathrm{pH}$ が 7.5 のトリプシンに似たセリンプロテアーゼであり, $\alpha_{\mathrm{S} 2}$ 力ゼインと $\beta$ カゼインを中心に作用する

一方, 凝乳酵素はレンネットと呼ばれ, セミハー ドノハードチーズでは乳を固めるために必須の添加物 である。現在利用されているレンネットは大きく 3 種 類に分類され，子ウシの第 4 胃から抽出する子ウシレ ンネット, その主活性であるキモシンの遺伝子を微生 物に導入して生産させた遺伝子組み替えレンネットお よび凝乳活性を持つカビから調製される微生物レンネ ットがある。

子ウシレンネットは伝統的に使用され, その凝乳活 性の本体はキモシンである。キモシン以外に消化酵素 であるペプシンも10〜50\%含まれている。キモシン は，酸性（又はアスパラギン酸）プロテアーゼに分類

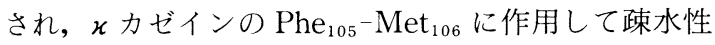
の高いパラ火力ゼインと水溶性のグリコマクロペプ チドに分解する。パラ に残り, 分解により露出した疎水性の高い部分どうし が凝集してカードを形成する。キモシンは凝乳中は他 のカゼインを分解しないと考えられているが, 熟成中 では $\beta$ カゼインの $\operatorname{Leu}_{192}-\mathrm{Tyr}_{193}, \alpha_{\mathrm{s} 1}$ カゼインの $\mathrm{Phe}_{23}-\mathrm{Phe}_{24}$ などに作用する ${ }^{1)}$ 。ペプシンは非特異的 に分解するため, 過剰に含まれると凝乳を阻害して収 率を悪くしたり，チーズ中に苦味を生じさせる。最近， BSE (bovine spongiform encephalopathy) いわゆ る狂牛病の影響で, EUから子ウシレンネットの入手 が困難となった。国内では狂牛病が発生していない才 ーストラリアなどの国から入手できるのみとなってい る。

組換えレンネットは微生物にキモシンの遺伝子を組 み込んで生産させ，その生産物を抽出した遺伝子組み 替え添加物であり, キモシンのみの活性しか持たない ため, 凝乳に最も適している。子ウシレンネット使用 に比べて宗教的な問題も避けることができるため, 世 界的に使用されている。日本では法的には認めれてい るが，「遺伝子組換え」に対する消費者の理解がまだ 不充分であるために使用されていない。

微生物レンネットは, Rhizomucor (旧名 Mucor) miehei などの凝乳活性をもつカビから抽出した酵素 であり，狂牛病の影響で広く使用されることとなった。 キモシンに比べて作用部位が異なり, また, 凝乳活性
がやや劣っていたり, 苦味を出しやすいなど特徴があ るため, キモシン含有レンネットのチーズ製造法の微 修正が必要である。最近, 凝乳活性がキモシン含有レ ンネットと遜色のない微生物レンネットが日本で開発 されている。

いずれの酵素もタンパク質をペプチドに分解するま でであり，旨味のもととなる遊離アミノ酸を生成する ためには乳酸菌のペプチダーゼが必要となる。

\section{3. 乳酸球菌のタンパク質分解酵素群}

ナチュラルチーズ製造の際に乳の凝固形成を助け, その凝固物（カード）から水分を減らすため添加する 乳酸菌をスターターと呼ぶ。乳酸球菌の中で Lactococcus lactis subsp. lactis および Lactococcus lactis subsp. cremoris（以下 L. lactis）はスターター として数多くのチーズに利用されているため, 研究が 進んでいる。過去 15 年の間，このタンパク質分解酵 素は数多く分離同定され，その特性が明らかとなって いる ${ }^{2,3,4,5)}$ 。

プロティナーゼは乳タンパク質であるカゼインをぺ プチドに分解する endo 型の酵素で正式にはエンドペ プチダーゼという名称である。プロティナーゼはその 基質特異性により, PrtP I と PrtP IIIの 2 種類に分

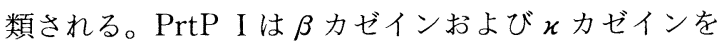
基質をするのに対し， PrtP III はこれらに加えて $\alpha_{\mathrm{s} 1}$ カゼインを分解できる。また, 同じく endo 型ではあ るが, カゼインなどのタンパク質は分解できないが, 抢よそ 30 残基以下のペプチドに作用し, さらに小さ なペプチドに分解するオリゴペプチダーゼも 4 種類 $\left(\mathrm{PepO}_{1}, \mathrm{PepO}_{2}, \mathrm{PepF}_{1}\right.$ および $\left.\mathrm{PepF}_{2}\right)$ 発見されて いる。

exo 型の酵素としては, ペプチドのアミノ酸を N (アミノ基)末端側から一つずつ遊離させ，広い基質特 異性をもつアミノペプチダーゼである PepN と PepC, $\mathrm{N}$ 末端がグルタミン酸またはアスパラギン酸のある ペプチドに高い特異性をもつ PepA どがある。ま た，ジペプチドのみを分解するジペプチダーゼ $(\mathrm{PepV})$ ，トリペプチドに作用し $\mathrm{N}$ 末端のアミノ酸を 遊離させるトリペプチダーゼ (PepT) も発見されて いる。

プロリンを含むぺプチドに作用する特異的なペプチ ダーゼも数多く研究されており， $\mathrm{N}$ 末端にプロリン 
を含むぺプチドに作用し，プロリンを遊離させるイミ ノペプチダーゼ (PepI)， $\mathrm{N}$ 末端から 2 番目にプロリ ンをもつ配列のペプチドに作用して X-Pro（X はア ミノ酸を示す) のジペプチドを遊離させるX-プロリ ルジペプチジルアミノペプチダーゼ $(\mathrm{PepX}), \mathrm{X}$ Proのジペプチドを分解するプロリダーゼ (PepQ) およびPro-Xのジペプチドを分解するプロリナーゼ (PepR) が発見されている。

\section{4. 乳酸桿菌のタンパク質分解酵素群}

チーズに関わる乳酸桿菌は，スターターとして使用 されるものと，スターターとして添加していないにも 関わらず，熟成 2〜3ヶ月から優勢となるものに分け られる。前者としては, 高温性乳酸菌である Lactobacillus helveticus およびLactobacillus delbruckii subsp. bulgaricus, 後者では中温性乳酸菌で ある Lactobacillus casei および Lactobacillus paracase $i$ が重要であり, これらのタンパク質分解酵素群 が研究されている。これまで, L. helveticus は 9 種類, L. delbruckii subsp. bulgaricus は 11 種類, L. casei/ L. paracasei は 6 種類の酵素が発見されており, これ らの酵素の大部分は，L. lactis の酵素の各タイプに分 類され ${ }^{5)}$, 同じタイプのものが発見されている。しか し，L. lactis のプロティナーゼおよびペプチダーゼか ら調製したモノクローナル抗体は L. casei の一部を除 いては反応せず，ポリクローナル抗体についてもアミ ノペプチダーゼ PepC を除き, 反応したタンパク質は 分子量の全く異なるものであった6)。また，タイプは 同じでも基質特異性が異なる酵素も見つかっており, 例えば，L. lactis 由来のアミノペプチダーゼ PepN は $\mathrm{N}$ 末端にプロリンがあると分解できないが，L. helveticus のアミノペプチダーゼは PepN と同じ金属 プロテアーゼで同等の広い基質特異性をもつが，さら に， $\mathrm{N}$ 末端にプロリンのあるペプチドも分解できる イミノペプチダーゼ活性を有する7)。

総じて乳酸桿菌は乳酸球菌 L. lactis に比べてタン パク質分解活性が高く, 特にL. helveticus はプロリ ンを含むぺプチドを分解する能力が高いため ${ }^{81}$, 後述 するようにチーズへの応用が進んでいる。

\section{5. タンパク質分解酵素の局在性}

乳酸菌のタンパク質分解酵素が菌体のどこに存在す
るかを明らかにすることは, 乳酸菌のタンパク質分解 機構を解明するために重要であるとともに，チーズ中 で効率的にタンパク質分解を起こさせ, 呈味性の遊離 アミノ酸を増やしていくかを考える上で極めて重要で ある。

L. lactis のプロティナーゼは細胞膜にアンカーをお ろした細胞壁，つまり菌体外に存在する9)。オリゴぺ プチダーゼを含むぺプチダーゼ群はイムノゴールドラ ベル法を用いた電子顕微鏡観察などにより，菌体内に 存在することが報告されている10)。また，ペプチダー ゼの塩基配列にシグナル配列を含まないこともぺプチ ダーゼが菌内に留まっていることを裏付ける証拠の一 つとなっている。L. helveticus のペプチダーゼ群につ いても，その塩基配列に L. lactis と同様な傾向が認 められることから，菌体内に存在すると推定されてい る。

乳酸菌のタンパク質分解機構は, 菌体外のタンパク 質を菌体外にあるプロティナーゼでぺプチドに分解し， 生じたペプチドを細胞膜上にある輸送システムを使っ て菌体内に取り込んでいる。この輸送システムは数多 く発見されており，菌体外のアミノ酸が直接菌体内に 取り込めるような輸送システムの他，ジペプチドまた はトリペプチドを輸送する DtpT と DtpP，扔よびオ リゴペプチド（アミノ酸 4 個から 11 個程度）を輸送 する Opp が報告されている3)。このように乳酸菌はア ミノ酸を菌体内に蓄え, 増殖のために必要となる夕ン パク質のパーツとしている(第 1 図)。

\section{6. チーズ熟成における乳酸菌の自己溶菌の意義}

チーズ中でレンネット，プラスミンおよび乳酸菌の プロティナーゼで分解されたペプチドを遊離アミノ酸 に分解させるためには, ペプチドと乳酸菌体内に存在 するぺプチダーゼ群の接触機会を増やす必要がある。

つまり，苦味をもつぺプチドを旨味などの呈味性を有 する遊離アミノ酸に分解するペプチダーゼ，特にアミ ノペプチダーゼが菌体からチーズ中に放出されなけれ ばならない。そのため, 一連のペプチダーゼの特性把 握研究の後、乳酸菌の自己溶菌に関する研究が行われ ている。

もともと乳酸菌は分裂時に細胞壁の一部を壊す必要 があるために，細胞壁を分解する溶菌酵素をもってい る。細胞壁の構造を考えると, N-アセチルムラミダ 


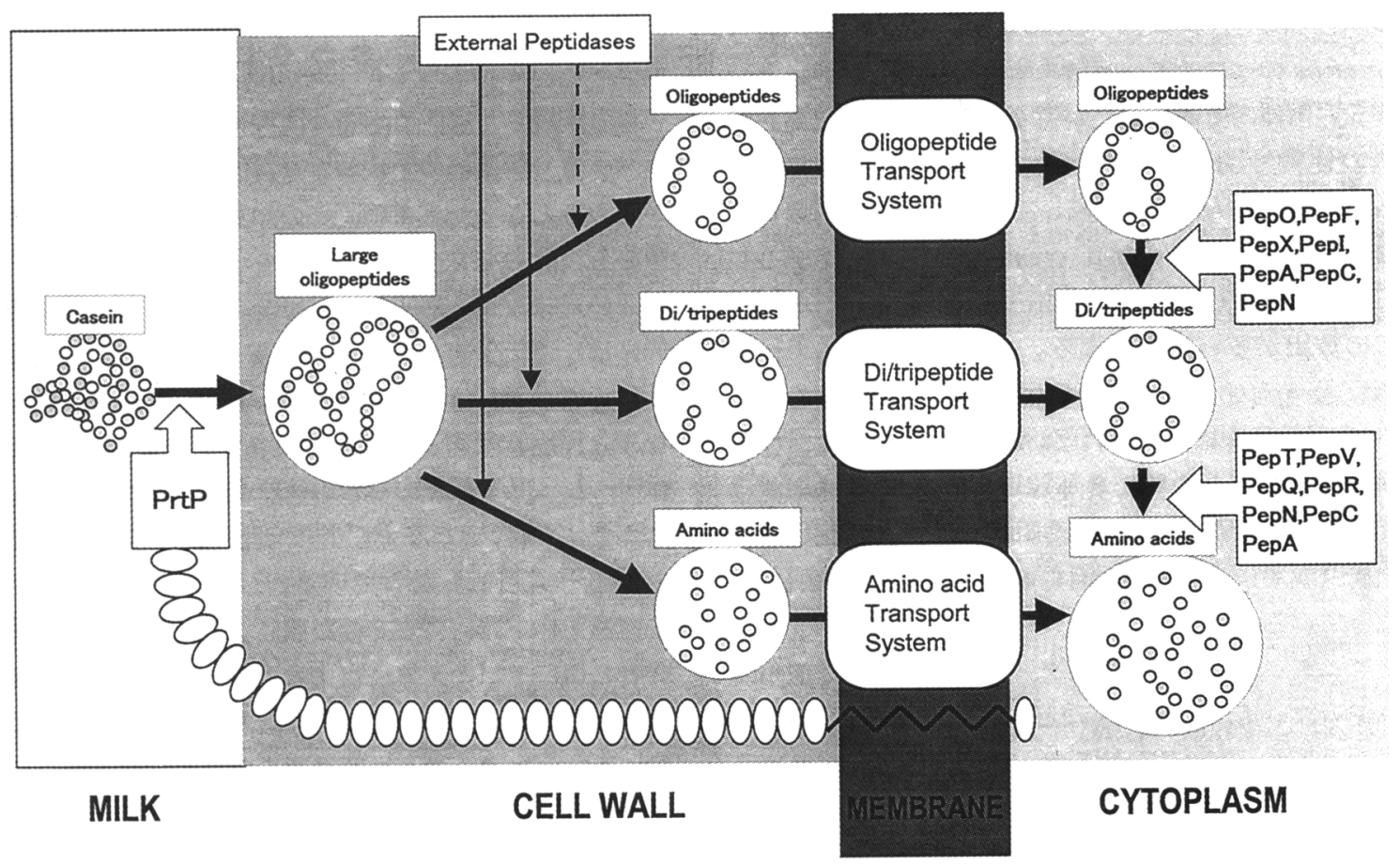

第 1 図 乳酸菌のタンパク質分解機構のモデル

ーゼ，N-アセチルグルコサミニダーゼ㧍よびエンド ペプチダーゼなどが必要となるが，L. lactis で研究が 進んでいるのは $\mathrm{N}-$ アセチルムラミダーゼ AcmA で ある。本酵素はその遺伝子配列が決定されており, 活 性のない前駆体が $46 \mathrm{kDa}$ ，活性のある成熟体が 41 $\mathrm{kDa}$ と推定されている ${ }^{11)}$ 。AcmA の遺伝子欠損株を 用いた研究により，細胞分裂時に不可欠であるととも

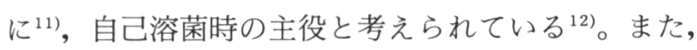
AcmA は L. lactis の細胞表層にあるプロティナーゼ PrtP I によってその活性が急速に低下するが，PrtP IIIでは活性への影響は低い13)。この他，L. lactis では $\mathrm{N}$-アセチルグルコサミニダーゼ活性をもつ AcmB も 発見されている ${ }^{14)}$ 。

L. helveticus については, 溶菌活性を持つ, 2 種類 のタンパク質（42.4 kDa と 29.1〜32.8kDa）が部分 精製されており ${ }^{15)}$, 詳細な研究はこれからである。

チーズ中における乳酸菌の自己溶菌は, 製造時の加 塩, 温度変化および $\mathrm{pH}$ 変化などの外部ストレスによ り誘発または活性化されていると考元らる。また, 乳酸菌がプロファージを含んでいるために自己溶菌が 誘発される場合もある。一方, チーズの熟成促進を目
的に, 積極的に自己溶菌させるために, 加熱処理, 凍 結融解処理, リゾチーム処理, 溶媒処理, 噴霧乾燥処 理および凍結乾燥処理することにより, スターターを 衰弱化する方法が研究されてきた。しかし，これらの 方法は, コスト面および安全面などで問題があり, 広 く普及している技術はない备。

これに対し, 自己溶菌の起こりやすい乳酸菌をス夕 ーターとして使う方法は, より経済的で現実的な方法 である。また, 自己溶菌酵素は菌体から離れても作用 するため ${ }^{12}$, 自己溶菌しやすい乳酸菌をチーズに加え ると, 他の乳酸菌の溶菌促進も期待できる。このよう に, 自己溶菌しやすい乳酸菌をチーズ製造に利用する ことができれば, 大量のアミノ酸を含み, 旨味と芳醇 な味わいのチーズを短期間の熟成で得られる可能性が 高い。

\section{7. チーズへの応用例}

スターターに含まれているL. lactis のチーズ中の 溶菌について古くからその現象が確認されており, 寸 でに 1970 年代に苦味がなくできばえの良いチーズ中 のスターターは生菌数が少ないことが観察されてい 


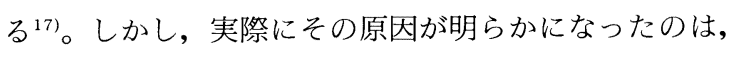
L. lactis のペプチダーゼ群の単離精製が行われ, その 存在が菌体内であることが明らかになり, 自己溶菌酵 素の性質も明らかになった後である。同様に，L. lactis subsp. lactis と比較してチーズ中の生菌数が少 なくなる L. lactis subsp. cremoris をスターターとし て好んで使用していたのは自己溶菌によるぺプチダー ゼの放出が多い理由による。また，プロティナーゼ PrtP I を有する乳酸菌を使用したチーズが苦くなる のは, PrtP I によって自己溶菌酵素 AcmA の活性が 弱まるためだと説明できる。このようにL. lactis は 元々スターターとして使用されているため, 自己溶菌 の研究成果はチーズ製造時における経験則の解明に役 立っている。

チェダー,ゴーダではスターターとして通常使用さ れていない L. helveticus などの乳酸桿菌は, L. lactis に比べてタンパク質分解活性, 自己溶菌活性が高いた め, 追加スターターなどの添加剤として研究が盛んで あり，実際に工業的に実現している例もある。

チェダーでは, 溶菌活性の高いL. helveticus を利 用して風味向上 ${ }^{18)}$, 熟成促進 ${ }^{19)}$, 低脂肪チーズへの風 味増強 ${ }^{20)}$ などに成功している。

ゴーダにおいてもアミノペプチダーゼ活性が高く, 溶菌活性の高いL. helveticus を利用して国産ナチュ ラルチーズが製造されている。この菌株のアミノペプ チダーゼ活性は平均值に比べて 3 倍以上高く帛, チー ズ中に抢ける生菌数も 8 週間以内に $1 / 10^{5}$ 以下となる。 このチーズは L. helveticus を利用していない通常ゴ ーダチーズに比べて熟成 4 ケ月で総遊離アミノ酸量が 2 倍以上あり, 熟成 7 ケ月程度でチロシンの結晶がチ ーズ中に析出する。チロシンはアミノ酸の中で最も溶 解度が低く,この結晶の出現はチーズ中に遊離アミノ 酸が多量に含まれることを示す。通常, この現象は熟 成 1 年〜 1 年半以上のゴーダでなければ認められず, 結晶のあるチーズは濃厚な風味が好きなチーズファン に珍重されている。風味についてもコクと旨味がある チーズに仕上がっている。このチーズは現在, 家庭用 のプロセスチーズ原料として主に使用されており，ク セのない味付けが多い日本のプロセスチーズの商品群 の中で熟成タイプの風味が際だっている。

\section{8. おわりに}

以上解説した膨大で地道な研究により, 乳酸菌の夕 ンパク質分解機構の全貌抢よび自己溶菌機構の大部分 が明らかとなった。また, この知見を応用して, 乳酸 菌のもつ能力をフルに利用したセミハード/ハードチ 一ズの風味改良, 熟成促進が可能となっている。技術 的には，遺伝子組み替え技術を用いて， $\mathrm{NaCl} て ゙$ 誘導 されるプロモーターに溶菌酵素 AcmA の遺伝子をつ なぎ, 加塩時に自己溶菌が起きるL. lactis の組換え 体 ${ }^{21)}$,L. helveticus の複数のペプチダーゼ遺伝子を組 込んでL. lactis でペプチダーゼ生産可能な組換え体 の創出 ${ }^{22)} も$ 可能となっている。しかし，これら遺伝 子組換え体が如何に安全性が確認されたとしても, 消 費者の遺伝子組換え体に対する拒絶は根強いために商 品に使用することは難しい。むしろこれらの研究成果 は，新しいスターターを開発するための知見として利 用した方が良いと考える。もしくは，天然の乳酸菌の 能力を最大限に利用するための分析手法として使用す べきである。

乳酸菌のタンパク質分解活性および自己溶菌活性は, 菌種ではなく菌株に依存することが確認されてお $り^{8,15)}$, 適切なスターターを開発するためには, 地道 なスクリーニングが必要となる。美味しいチーズを製 造するためには，タンパク質分解活性が強く，そのバ ランスが良いだけではなく，自己溶菌しやすい乳酸菌 をスターターとして選択することも極めて重要なポイ ントとなる。さらに, 風味に対する遊離アミノ酸, ペ プチドと各ペプチダーゼの関係がさらに解明されれば, 乳酸菌によるチーズ風味の設計がさらに精度の高いも のとなるであろう。

<雪印乳業(株開発企画室 $>$

\section{参考文献}

1) Fox, P.F., Law, J., McSweeney, P.L.H., \& Wallace, J. : Cheese : Chemistry, physics and microbiology (2 d ed., Vol.1).Chapman \& Hall, 389 (1993)

2) Kunji, E.R.S., Mierau, I., Hagting, A., Poolman, B. \& Konings, W.N. : Antonie Van Leeuwenhoek, 70, 187 (1996)

3) Nakajima, H. \& Sasaki, M. : Milk Science, 
46, 245 (1997)

4) Fox, P.F., Guinee, T.P., Cogan, T.M. \& McSweeney, P.L.H. : Fundamentals of cheese science. An Aspen Publication, 236 (2000)

5) Christensen, J.E., Dudley, E.G., Pederson, J. A. \& Steele, J.L. : Antonie van Leeuwenhoek, 76, 217 (1999)

6) Sasaki, M., Bosman, B.W. \& Tan, P.S.T. : Journal of Dairy Research, 62, 611 (1995)

7) Sasaki, M., Bosman, B.W. \& Tan, P.S.T. : Microbiology, 142, 799 (1996)

8) Sasaki, M., Bosman, B.W. \& Tan, P.S.T. : Journal of Dairy Research, 62, 601 (1995)

9) Haandrikman, A.J., Meesters, R., Laan, H., Konings, W.N., Kok, J. \& Venema, G. : Appl. Environ. Microbiol., 57, 1899 (1991)

10) Tan, P.S.T., Chapot-Chartier, M.-P., Pos, K. M., Rousseau, M., Boquien, C.-Y., Gripon, J.C. \& Konings, W.N. : Appl. Environ. Microbiol., 58, 285 (1992)

11) Buist, G., Kok, J., Leenhouts, K.J., Dabrowska, M., Venema, G. \& Haandrikman, A.J. : J. Bacteriol., 177, 1554 (1995)

12) Buist, G., Karsens, H., Nauta, A. Van Sinderen, D., Venema, G. \& Kok, J. : Appl. Environ. Microbiol., 63, 2722 (1997)
13) Buist, G., Venema, G. \& Kok, J. : J. Bacteriol., 180, 5947 (1998)

14) Huard, C., Miranda, G., Wessner, F., Bolotin, A., Hansen, J., Foster, S.J. \& Chapot-Chartier, M.P. : Microbiology., 149, 695 (2003)

15) Valence, F. \& Lortal, S. : Appl. Environ. Microbiol., 61, 3391 (1995)

16) Klein, N. \& Lortal, S. : Int. Dairy Journal, 9, 751 (1999)

17) Martley, F. G. \& Lawrence, R. C. : New Zealand Journal of Dairy Science and Tech. nology, 7, 38 (1972)

18) Drake, M.A., Boylston, T.D., Spence, K.D. \& Swanson, B.G. : Food Research International, 29, 381 (1996)

19) Hannon, J.A., Wilkinson, M.G., Delahunty, C. M., Wallace, J.M., Morrissey, P.A. \& Beresford, T.P.: Int. Dairy Journal, 13, 313 (2003)

20) Drake, M.A., Boylston, T.D., Spence, K.D. \& Swanson, B.G. : Food Research International, 30, 35(1997)

21) Sanders, J.W., Venema, G. \& Kok, J. : Appl. Environ. Microbiol., 63, 4877 (1997)

22) Joutsjoki, V., Luoma, S., Tamminen, M., Kilpi, M., Johansen, E. \& Palva, A. : J. Appl. Microbiol., 92, 1159 (2002)

\section{執筆者紹介（順不同・敬称略）}

\section{佐々木正弘 $<$ Masahiro SASAKI >}

昭和 36 年 4 月 6 日生れ<勤務先とその所在地 $>$ 雪 印乳業株式会社開発企画室， テ 350-1165 埼玉県川 越市南台 $1-1-2<$ 略歴>昭和 61 年北海道大学大学 院農学研究科前期課程修了, 同年雪印乳業株式会社入 社, 札幌研究所, 平成 2 年 技術研究所, 平成 3 年 〜雪印ヨーロッパ研究所, 平成 7 年 技術研究所, 平 成 10 年 札幌研究所, 平成 14 年 現職, 同主席企画 員<抱負 $>$ 日本人の味覚にあった美味しいナチュラル チーズの研究開発を推進したい。く趣味>（体力はか なり衰えたが）野球，テニス，スキー

\section{吉田 元 $<$ Hajime YoshidA $>$}

昭和 22 年 3 月 20 日生れ<勤務先とその所在地 $>$ 種 智院大学, $=612-8156$ 京都市伏見区向島西定請 $70<$ 略歴>昭和 44 年 3 月京都大学農学部水産学科卒業, 昭和 49 年同大学院農学研究科農芸化学専攻博士課程 単位修得退学, 昭和 53 年種智院大学専任講師, 平成 3 年同教授, 現在に至る。く抱負>埋もれた史実を発 掘し, 日本酒造史を書いてみたい。く趣味>古いカメ ラで写真をとること, 鉄道乗り歩き 